\title{
Islet transplantation outcomes in mice are better with fresh islets and exendin-4 treatment
}

Received: 11 March 2005 / Accepted: 7 June 2005 / Published online: 23 August 2005

(C) Springer-Verlag 2005

\begin{abstract}
Aims/hypothesis: Although islet transplantation in diabetes holds great promise, two or three donor pancreases are usually required to achieve normoglycaemia in human or rodent recipients. We investigated whether there were differences between fresh and cultured islets in terms of transplantation outcome. We also investigated the effects of normoglycaemia during engraftment and the effects of exendin-4, a glucagon-like peptide-1 receptor agonist, on islet transplantation. Materials and methods: Seventy-five fresh islets were transplanted to the right kidney of diabetic mice and 425 fresh islets were transplanted to the left kidney. The mice were treated with exendin- 4 or vehicle for 14 days, after which the large graft was removed by left nephrectomy. In a separate set of experiments, islets cultured in the presence or absence of exendin- 4 for $72 \mathrm{~h}$, or fresh islets, were transplanted to diabetic mice. In both sets of experiments, blood glucose levels were monitored. Results: Compared with cultured islets, fresh islets were more effective at reversing hyperglycaemia in mice. The treatment of the recipient mice with exendin- 4 did not have beneficial effects on glucose homeostasis. However, when islets are cultured, exendin- 4 treatment increases the rate of reversal of hyperglycaemia, but not to the degree of fresh islets. Conclusions/ interpretation: Fresh islets are more effective than cultured islets at reversing hyperglycaemia. Exendin-4 has beneficial effects on islet transplantation.
\end{abstract}

Keywords Diabetes $\cdot$ Exendin-4 $\cdot$ Islet transplantation

Abbreviations GLP-1: glucagon-like peptide-1 - IPGTT: intraperitoneal glucose tolerance test - RM ANOVA: repeated-measurement ANOVA

\footnotetext{
A. King · J. Lock · G. Xu · S. Bonner-Weir · G. C. Weir $(\bowtie)$ Section on Islet Transplantation and Cell Biology, Joslin Diabetes Center, Harvard Medical School, Boston, MA, USA

e-mail: gordon.weir@joslin.harvard.edu

Tel.: +1-617-7322581

Fax: +1-617-7322650
}

\section{Introduction}

Transplantation of islets of Langerhans can reverse hyperglycaemia in humans as well as in rodent models of diabetes; however, each recipient usually requires islets from two or three donor pancreases $[1,2]$. Despite recent improvements in human islet isolation, it is evident that what would seem to be sufficient islet mass usually does not truly normalise glucose levels, as most recipients remain glucose intolerant [3]. It is generally assumed that considerable islet loss occurs due to ischaemia during the immediate transplantation period combined with immunological destruction and the toxic effects of immunosuppressive agents. The amount of beta cell mass in the hepatic graft needed to produce insulin independence is not known but may be $20-40 \%$ of normal mass in the pancreas. Because of the limited available supply of pancreases from cadaver donors [4], much attention is focused upon ways in which islet quantity and quality could be improved. In the present study, we have studied several parameters that may affect the outcome of islet transplantation: engraftment under normoglycaemic conditions, the use of freshly isolated islets and the use of exendin- 4 .

Exendin-4 is an agonist of the glucagon like peptide-1 (GLP-1) receptor with a longer half-life than GLP-1 [5]. This peptide has previously been shown to increase beta cell replication and islet neogenesis [6]. Moreover, GLP-1 and exendin- 4 have been reported to reduce beta cell apoptosis [7, 8]. The Edmonton protocol used freshly isolated islets rather than cultured, although it was unclear how much of an effect this contributed to the favourable outcome of the transplants [2]. Since then, the Edmonton group and others have reverted to transplanting cultured islets [9-11]. It is therefore of interest to investigate whether there is indeed any advantage in transplanting freshly isolated islets. It has previously been shown that engraftment under normoglycaemic conditions tends to improve the outcome of islet transplantation [12-14]. In the present study we therefore investigated the benefit of fresh islets, engraftment under normoglycaemic conditions and exendin-4 treatment for the success of transplantation of a 
minimal number of islets. The aim of the study was to optimise suboptimal islet transplantations.

\section{Materials and methods}

Animals Male C57BL/6AF1 mice (Jackson Laboratories, Bar Harbor, ME, USA) aged 6-10 weeks were used as donors and recipients of islets grafts. Recipient animals were made diabetic by a single i.p. injection of streptozocin (Sigma, St Louis, MO, USA) $180 \mathrm{mg} / \mathrm{kg}$ body weight, freshly dissolved in citrate buffer ( $\mathrm{pH} 4.5$ ). Only those mice with a blood glucose concentration greater than $20 \mathrm{mmol} / 1$ were used as recipients. Blood glucose concentrations were determined using a glucose meter (Accu-Check; Boehringer-Mannheim Biochemicals, Indianapolis, IN, USA) with blood obtained from a snipped tail. All animal experiments were approved by the Joslin Animal Care Committee.

Islet isolation and culture Islets were isolated by using collagenase digestion followed by separation using a density gradient, as previously described in detail [1]. Briefly, under anaesthesia, a laparatomy was performed and the pancreas exposed. After ligation at the ampulla of Vater, $2 \mathrm{ml} \mathrm{col}-$ lagenase solution (Liberase RI; Roche, Indianapolis, IN, USA) were injected into the pancreas via the common bile duct. The pancreas was removed and incubated in a stationary water bath for approximately $20 \mathrm{~min}$ at $37^{\circ} \mathrm{C}$. The islets were separated by a density gradient (Histopaque-1077; Sigma) centrifuged at $1,750 \mathrm{~g}$ for $20 \mathrm{~min}$. After washing, islets were handpicked and either transplanted immediately (within $1 \mathrm{~h}$ ) or cultured for $72 \mathrm{~h}$ in RPMI 1640 medium containing $10 \%$ foetal calf serum and supplemented with antibiotics in the presence or absence of $1 \mathrm{nmol} / \mathrm{kg}$ exendin-4 (Sigma).

Groups of approximately 200 islets were cultured in Petri dishes $(60 \mathrm{~mm}$ diameter) containing $5 \mathrm{ml}$ medium. The medium was changed the day after the islets were put in culture.

Islet transplantation Animals were anaesthetised using methoxyflurane (Schering-Plough, Omaha, NE, USA) and placed on a heated plate for surgery. For single transplants, the left kidney was used. The kidney was exposed through a lumbar incision and the kidney capsule was incised. Using a Hamilton syringe (Fisher, Pittsburg, PA, USA) and polyethylene tubing (Cole Parmer, Vernon Hills, IL, USA), islets were placed under the kidney capsule as previously described [15]. The incision in the kidney capsule was then cauterised and the peritoneum was sutured. The skin was then closed using staples, and animals were allowed to recover under a warm lamp.

Insulin release Islets were isolated freshly or cultured in the presence or absence of exendin- 4 for $72 \mathrm{~h}$ as described above. Exendin- 4 was not present in the medium during the insulin release experiments. For each condition (fresh, cultured or cultured with exendin-4), each of four replicate groups of 50 islets was placed in $1 \mathrm{ml}$ RPMI 1640 containing $1.7 \mathrm{mmol} / 1$ glucose and incubated for $30 \mathrm{~min}$ at $37^{\circ} \mathrm{C}$. After this pre-incubation, the medium was removed and fresh medium containing $1.7 \mathrm{mmol} / \mathrm{l}$ glucose was added. The islets were then incubated at $37^{\circ} \mathrm{C}$ for $60 \mathrm{~min}$. The medium was then removed and stored at $-20^{\circ} \mathrm{C}$ and fresh medium containing $16.7 \mathrm{mmol} / \mathrm{l}$ glucose was added before an additional incubation for $60 \mathrm{~min}$ at $37^{\circ} \mathrm{C}$. Islets were then harvested and washed in PBS before addition of either acid-ethanol or high-salt buffer $(2 \mathrm{~mol} / 1 \mathrm{NaCl}$, $10 \mathrm{mmol} / 1 \quad \mathrm{NaH}_{2} \mathrm{PO}_{4}, 16 \mathrm{mmol} / 1 \mathrm{Na}_{2} \mathrm{HPO}_{4}, 2 \mathrm{mmol} / \mathrm{l}$ EDTA, $\mathrm{pH}$ 7.4) for measurement of insulin or DNA contents, respectively. The medium was stored at $-20^{\circ} \mathrm{C}$ until insulin measurement. Eight independent isolations of islets were used for these experiments.

Insulin measurement Islets were sonicated in acid-ethanol, and insulin was extracted at $4^{\circ} \mathrm{C}$ overnight. Samples were then stored at $-20^{\circ} \mathrm{C}$ until insulin measurement. After appropriate dilution, insulin from the islets and from the medium was measured using an RIA (Linco Research, Inc., St Charles, MO, USA) with rat insulin as standard.

DNA measurement Islets were sonicated in a high-salt buffer and then stored at $-20^{\circ} \mathrm{C}$ pending analysis of DNA content. DNA was measured using Hoechst dye and quantified by use of a spectrofluorimeter [16].

Experimental series The first experimental series was designed to test the efficacy of treatment of islet transplant recipients with exendin-4. To ensure a normoglycaemic environment, 425 fresh islets were transplanted under the left kidney capsule and a marginal number of 75 fresh islets were transplanted under the right kidney capsule of the mice. Immediately after the operation, the animals were injected i.p. with exendin-4 $(1 \mathrm{nmol} / \mathrm{kg})$ or vehicle (PBS; $10 \mu \mathrm{l} / \mathrm{g}$ body weight). Exendin-4 or PBS was then injected i.p. once daily in the morning for a period of 14 days. Nonfasting blood glucose levels were measured twice a week, always prior to exendin- 4 treatment. After 14 days, a nephrectomy of the left kidney that was carrying the 425-islet graft was done. Following the nephrectomy, blood glucose concentrations were measured every 1-2 days for the first week. Body weights were measured at the time of blood glucose measurements. Eight weeks after nephrectomy (10 weeks after transplantation) an i.p. glucose tolerance test (IPGTT) was carried out. Mice were injected i.p. with $2 \mathrm{~g} / \mathrm{kg}$ glucose, and their blood glucose concentrations were measured at $0,15,30,60,90$ and $120 \mathrm{~min}$.

In a second separate set of experiments, to examine the effect of culture conditions upon transplant outcomes, 150 freshly isolated or cultured islets were transplanted. Islets were cultured for $72 \mathrm{~h}$ in either the presence or absence of $1 \mathrm{nmol} / \mathrm{kg}$ exendin-4. In fresh and cultured islets, insulin release measurements were carried out as above. Additionally in cultured islets, the medium was changed after the first $24 \mathrm{~h}$, and accumulation of insulin in the medium was measured for the last $48 \mathrm{~h}$ of culture. Insulin and DNA contents of the islets were assessed as described above. In mice transplanted with fresh or cultured islets, 150 islets were transplanted under the capsule of the left kidney, and 
the blood glucose concentrations and body weights were measured weekly. In addition, mice transplanted with cultured islets (150 exendin-4-treated or control) were treated with exendin- 4 or PBS for the first 14 days after transplantation. After 100 days, nephrectomies were carried out on the mice that had become normoglycaemic.

Statistical analyses When two groups were compared, an unpaired the Student's $t$-test was used. When more than two groups were compared, ANOVA was used. In groups where measurements were repeated in the same animals at different time points, a repeated-measurement ANOVA (RM ANOVA) was carried out. If the difference between the ANOVA groups was significant, individual groups were compared using the Bonferroni post hoc test. To investigate differences in the number of days it took for mice to be cured after transplantation, a Kaplan-Meier survival curve was used. Cure was defined as two consecutive non-fasting blood glucose levels under $11.1 \mathrm{mmol} /$ 1. In all tests, a $p$ value of less than 0.05 was considered significant. Data are presented as means \pm SEM. ANOVA and $t$-tests were carried out using Sigmastat (Systat Software, Point Richmond, CA, USA) and Kaplan-Meier analysis was carried out using SPSS software (Chicago, IL, USA).

\section{Results}

Mice transplanted with a graft of 75 islets In diabetic mice transplanted with a graft of 75 islets alone, blood glucose concentrations were not lowered (Fig. 1). When 75 islets were transplanted to mice at the same time as a graft of 425 islets was implanted to the contralateral kidney, blood glucose concentrations of the mice were lowered both in mice treated with exendin- 4 and in the vehicle-treated mice. After removal of the 425 -islet grafts by nephrectomy on day 14 , the blood glucose levels rose transiently. There was no significant difference in the blood glucose levels

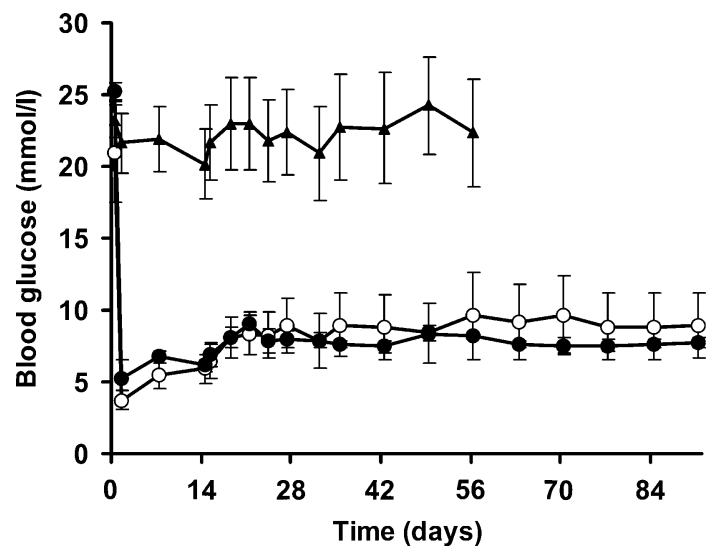

Fig. 1 Blood glucose concentrations of mice transplanted with two islet grafts: one containing 425 islets and one with 75 islets. The mice $(n=5-6)$ were treated with $1 \mathrm{nmol} / \mathrm{kg}$ exendin-4 (filled circles) or vehicle (open circles) for 14 days after transplantation, after which the graft containing 425 islets was removed. One group of mice was transplanted with 75 islets alone (filled triangles)

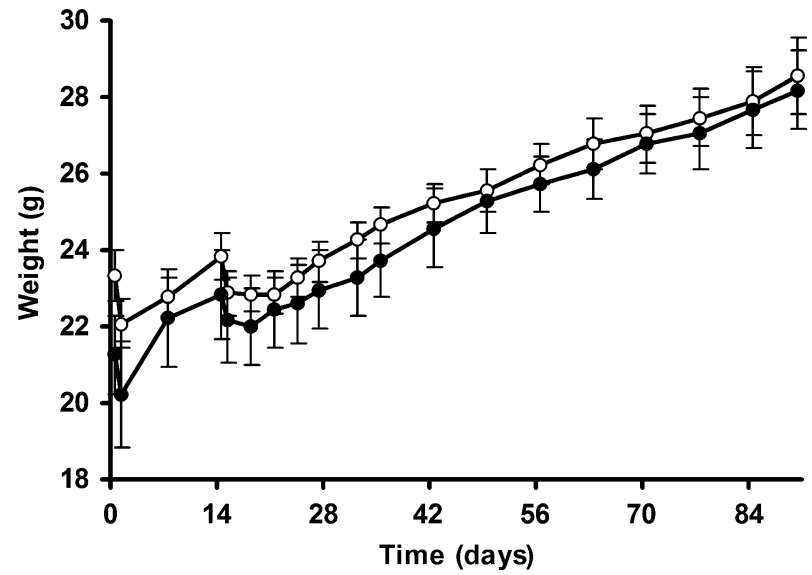

Fig. 2 Weight of mice transplanted with two islet grafts: one containing 425 islets and one 75 islets. The mice were treated with $1 \mathrm{nmol} / \mathrm{kg}$ exendin-4 (filled circles) or vehicle (open circles) for 14 days after transplantation, after which the graft containing 425 islets was removed $(n=5-6)$

between exendin-4-treated and vehicle-treated animals. It should be noted that one of six mice treated with PBS reverted to hyperglycaemia after the removal of the large graft. Animals with only a 75-islet transplant lost weight over the first 3 weeks (data not shown). Other animals initially lost weight the day after implantation of 500 islets, after which weights of exendin-4-treated and vehicletreated animals tended to increase (Fig. 2). After the nephrectomies and removal of the large graft, exendin-4treated animals had a decreased body weight for 4 days (one-way RM ANOVA with Bonferroni post hoc test. Day 14 vs days $15,18,21, p<0.001, p=0.009$ and $p=0.234$, respectively, $n=5$ ). One week after nephrectomy, mice treated with PBS continued to have decreased body weight relative to their pre-nephrectomy weights (one-way RM ANOVA with Bonferroni post hoc test. Day 14 vs days 15 , $18,21, p=0.001, p=0.002$ and $p=0.002$, respectively, $n=6$ ).

Eight weeks after the nephrectomy, IPGTTs were carried out on both groups of transplanted mice. The mouse in the vehicle-treated group that was hyperglycaemic (described

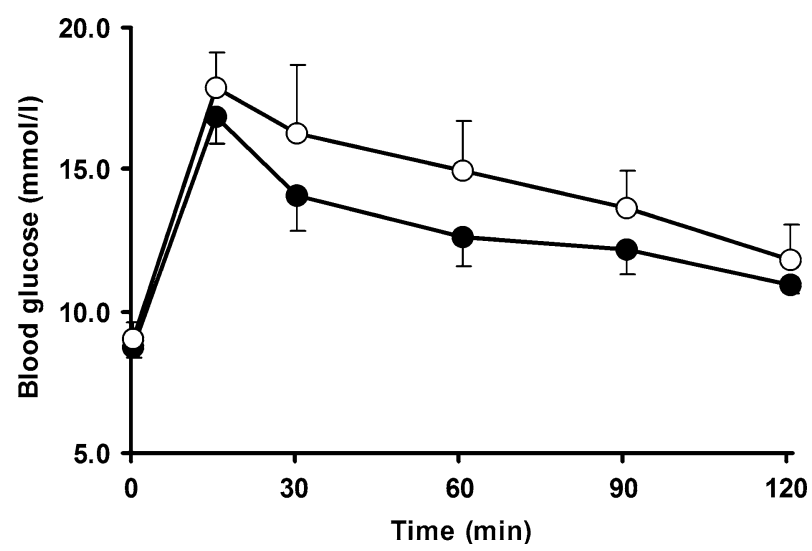

Fig. 3 IPGTTs in mice with a 75-islet graft, 8 weeks after a curative 425 -islet graft was removed. Mice ( $n=5$ in both groups) had been treated with exendin-4 (closed circles) or vehicle (open circles) for 14 days after transplantation 
Fig. 4 Percentage of mice $(n=9-11)$ remaining diabetic (blood glucose concentration $>11.1 \mathrm{mmol} / \mathrm{l})$ after transplantation of 150 fresh islets (open triangles) or islets cultured with (open circles) or without (closed circles) exendin-4

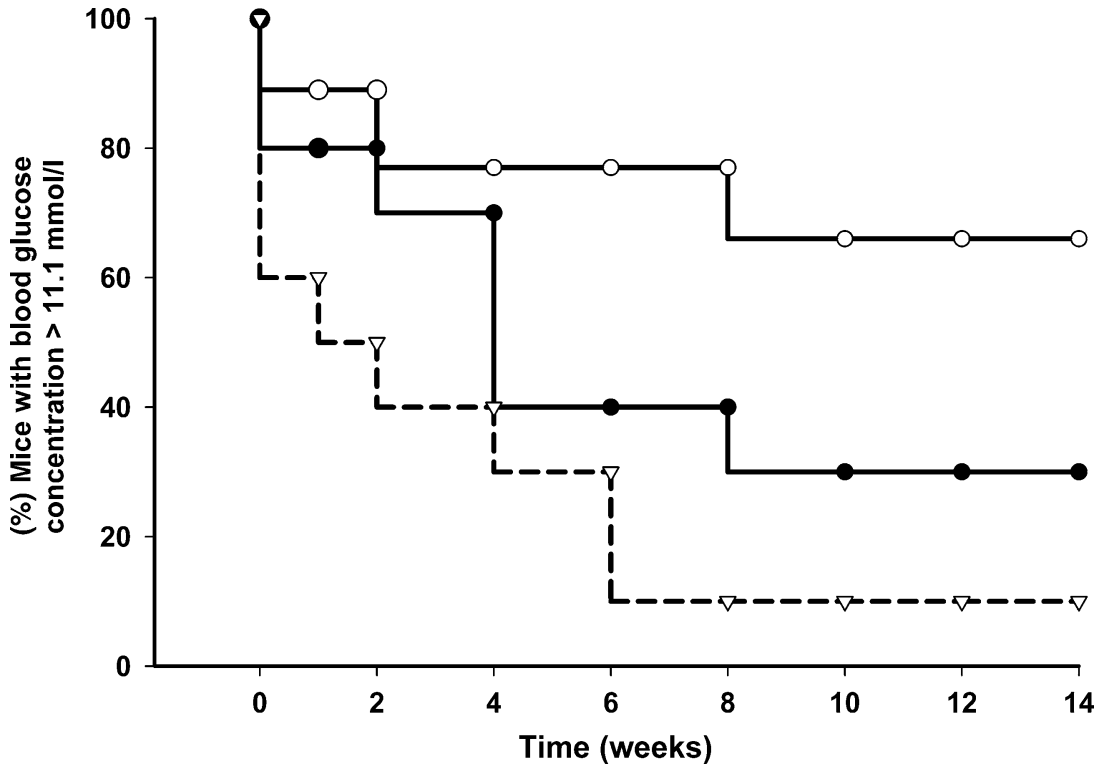

above) was excluded. There was no significant difference in the glucose tolerance of exendin-4-treated vs. PBS-treated mice (Fig. $3 ; p=0.3$ for treatment, two-way RM ANOVA, $n=5$ ). The histological finding of very few beta cells in the endogenous pancreases at the termination of the experiment indicated that the graft was maintaining normoglycaemia.

Mice transplanted with 150 islets After transplantation, these mice were monitored for 96 days. In those transplanted with fresh islets, $11 \%$ had not been cured by 96 days (Fig. 4). The average time to cure for these mice was $31 \pm 9$ days, with a median of 14 days. When cultured islets were transplanted, the time to cure was significantly longer, with an average of $81 \pm 10$ days ( $p=0.0018$, Kaplan-Meier, $n=9-10$ ); only $22 \%$ of mice in this group were cured. However, after transplantation of islets cultured with exendin-4, mice were cured after $58 \pm$ 10 days, with a median of 44 days $(p=0.0503$ in comparison with control cultured islets and $p=0.138$ in comparison with fresh islets, Kaplan-Meier, $n=9-10$ ).

The post-transplantation treatment with exendin- 4 did not improve the outcome of mice transplanted with either group of cultured islets as compared with those mice not injected with exendin-4 (mean time to cure: control cultured islets, exendin-treated mice: $74 \pm 10$ days vs $62 \pm 12$ days in exendin-cultured islets, exendin-treated mice, $n=$ 11-12).

In terms of average blood glucose concentrations (both cured and non-cured included), transplantation of 150 fresh islets lowered the blood glucose concentrations to $9.3 \pm 0.9 \mathrm{mmol} / 1$ at 90 days $(n=11)$, a lower value than in

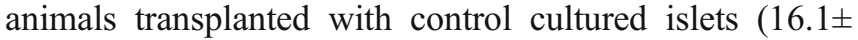
$2.4 \mathrm{mmol} / 1, p<0.05$, ANOVA with Bonferroni post hoc test, $n=9$ ). The blood glucose concentrations of mice transplanted with 150 exendin-4-cultured islets were not statistically different from mice transplanted with fresh islets $(11.0 \pm 1.8 \mathrm{mmol} / 1, p=1.0$ vs fresh islets, ANOVA with Bonferroni post hoc test, $n=10$ ).
Function of cultured islets The accumulation of insulin to the culture medium during the last $48 \mathrm{~h}$ of culture was, surprisingly, not significantly higher in exendin-4-treated islets $(4,470$ vs $3,556 \mathrm{ng}$ per 200 islets per $48 \mathrm{~h}, p=0.097$, $n=8)$. The insulin content was similar in both exendin-4and control-cultured islets ( $62 \pm 8$ vs $52 \pm 8 \mathrm{ng} /$ islet, respectively, $p=0.41, n=8, t$-test). Insulin release rates were also similar in both groups $(3.3 \pm 0.8$ and $4.6 \pm 1.6 \mathrm{ng} / 50$ islets for control and exendin-4-cultured islets, respectively, at $1.7 \mathrm{mmol} / 1$ glucose; $17.2 \pm 6.9$ and $17.2 \pm 2.1 \mathrm{ng} / 50$ islets at $16.7 \mathrm{mmol} / 1$ for control- and exendin-4-cultured islets, respectively). Fresh islets had increased DNA content $(15.5 \pm 2 \mathrm{ng} /$ islet in fresh islets compared with $11.2 \pm 0.6 \mathrm{ng} /$ islet in control cultured and $10.7 \pm 0.8 \mathrm{ng} /$ islet in exendin-4cultured islets, $t$-test: fresh islets vs control cultured islets, $p=0.045, n=4-6$ ).

\section{Discussion}

The ability of 75 islets to maintain normoglycaemia was dependent on the islets engrafting under normoglycaemic conditions. A normoglycaemic environment, in contrast to hyperglycaemia, provides better islet transplantation results $[14,17,18]$ for uncertain reasons that may include enhanced beta cell growth of the grafts [19], and/or avoidance of hyperglycaemia-induced increased oxygen demand with resulting hypoxia, a pro-apoptotic state of beta cells, and less-efficient vascularisation [20,21], although it seems that in the long term, vascular density is unchanged by hyperglycaemia [22]. It cannot be ruled out that nephrectomy leads to release of compensatory growth factors in the contralateral kidney where the 75-islet graft is situated, thus stimulating islet growth [23]; even so, a remarkably low number of islets was required to maintain normoglycaemia. In the mice transplanted with 75 fresh islets or 150 cultured islets, the treatment of the mice with exendin-4 did not improve the outcome with regard to the 
mean time to cure or blood glucose levels. However, it cannot be ruled out that although differences in blood glucose could not be detected, the exendin- 4 had subtle effects on the beta cell mass of the grafts. In animals with grafts of 75 islets, the body weights of the exendin-4treated animals were similar to those of PBS-treated animals, although the exendin- 4 mice tended to recover the weight loss after nephrectomy more quickly. It has previously been reported that exendin-4 slows gastric emptying, and therefore animals can lose weight [5]. However, it may be possible that the improvement in glucose homeostasis itself leads to a weight gain despite the effects on gastric emptying.

As few as 150 freshly isolated islets can reduce blood glucose concentrations in most diabetic mice, but the ability of 150 cultured islets to reduce blood glucose concentrations in diabetic mice seems to be limited. However, the presence of exendin-4 during islet culture led to a better outcome of islet transplantation, although not to the extent of fresh islets.

Since culture of islets often leads to central necrosis of the islets [24], increased success of the transplantation of fresh islets could be due to their greater viable beta cell mass. The fresh islets did have increased DNA content, although the insulin content was not significantly higher than in cultured islets. However, over this short time the DNA probably remained in non-viable cells and was measured. These data are consistent with a study by Rabinovitch et al. [25] in which an initial decrease in insulin content $20 \mathrm{~h}$ after culture had returned to the levels of fresh islets after $68 \mathrm{~h}$. The increased DNA content in fresh islets may also be due to the presence of other cells such as endothelial cells or exocrine cells. Another possible explanation of the success of transplanting freshly isolated islets may the intactness of their capillary network. The potential importance of donor endothelium in the revascularisation process has recently been shown [26]. Indeed, it has been noted that grafts from fresh islets have higher oxygen contents than those from cultured islets, even 1 month after transplantation [27].

The effect of exendin- 4 on the islets could be due to the proliferative and anti-apoptotic effects that this peptide has on beta cells [6-8]. However, there was no difference in either DNA or insulin content of exendin-4-cultured islets, indicating that any effect is most likely subtle. In line with this, the insulin accumulation during a $48 \mathrm{~h}$ period to the medium was similar in both exendin-4-cultured vs controlcultured islets, as was the glucose-induced insulin release. It also has not been ruled out that exendin- 4 affects other cells in the islet, such as endothelial cells or putative stem cells, which may affect transplantation outcome. The reason that some mice were cured only several weeks after transplantation is not known. One explanation could be an effect of the graft on the regeneration of the endogenous pancreas [28]; however, after nephrectomy of the graftbearing kidney, all animals reverted to hyperglycaemia. Thus, the presence of the graft was mandatory for maintaining normoglycaemia.

In conclusion, fresh islets are more effective in the reversal of hyperglycaemia in mice than cultured islets.
When islets are cultured, exendin- 4 in the medium leads to a more rapid reversal of hyperglycaemia after transplantation of the islets.

Acknowledgements This study was supported by grants from the National Institute of Health (DK 50657, U19DK6125), the Juvenile Diabetes Research Foundation, the Diabetes Research and Wellness Foundation and an important group of private donors. Help was also provided by the Joslin Diabetes and Endocrinology Research Center (DERC) supported by the National Institutes of Health (P30 DK36836-16). J. Fernandes is gratefully acknowledged for his technical help.

\section{References}

1. Montana E, Bonner-Weir S, Weir GC (1993) Beta cell mass and growth after syngeneic islet cell transplantation in normal and streptozocin diabetic C57BL/6 mice. J Clin Invest 91:780-787

2. Shapiro AM, Lakey JR, Ryan EA et al (2000) Islet transplantation in seven patients with type 1 diabetes mellitus using a glucocorticoid-free immunosuppressive regimen. N Engl J Med 343:230-238

3. Ryan EA, Lakey JR, Rajotte RV et al (2001) Clinical outcomes and insulin secretion after islet transplantation with the Edmonton protocol. Diabetes 50:710-719

4. Weir GC, Bonner-Weir S (1997) Scientific and political impediments to successful islet transplantation. Diabetes 46: $1247-1256$

5. Brubaker PL, Drucker DJ (2004) Minireview: Glucagon-like peptides regulate cell proliferation and apoptosis in the pancreas, gut, and central nervous system. Endocrinology 145: $2653-2659$

6. Xu G, Stoffers DA, Habener JF, Bonner-Weir S (1999) Exendin-4 stimulates both beta-cell replication and neogenesis, resulting in increased beta-cell mass and improved glucose tolerance in diabetic rats. Diabetes 48:2270-2276

7. Farilla L, Hui H, Bertolotto C et al (2002) Glucagon-like peptide-1 promotes islet cell growth and inhibits apoptosis in Zucker diabetic rats. Endocrinology 143:4397-4408

8. Li Y, Hansotia T, Yusta B, Ris F, Halban PA, Drucker DJ (2003) Glucagon-like peptide-1 receptor signaling modulates beta cell apoptosis. J Biol Chem 278:471-478

9. Shapiro AM, Nanji SA, Lakey JR (2003) Clinical islet transplant: current and future directions towards tolerance. Immunol Rev 196:219-236

10. Goss JA, Schock AP, Brunicardi FC et al (2002) Achievement of insulin independence in three consecutive type-1 diabetic patients via pancreatic islet transplantation using islets isolated at a remote islet isolation center. Transplantation 74:1761-1766

11. Hering BJ, Kandaswamy R, Harmon JV et al (2004) Transplantation of cultured islets from two-layer preserved pancreases in type 1 diabetes with anti-CD3 antibody. Am J Transpl 4:390-401

12. Merino JF, Nacher V, Raurell M, Biarnes M, Soler J, Montanya E (2000) Optimal insulin treatment in syngeneic islet transplantation. Cell Transplant 9:11-18

13. Ferrer-Garcia JC, Merino-Torres JF, Perez BG, Herrera-Vela C, Ponce-Marco JL, Pinon-Selles F (2003) Insulin-induced normoglycemia reduces islet number needed to achieve normoglycemia after allogeneic islet transplantation in diabetic mice. Cell Transplant 12:849-857

14. Juang JH, Bonner-Weir S, Wu YJ, Weir GC (1994) Beneficial influence of glycemic control upon the growth and function of transplanted islets. Diabetes 43:1334-1339

15. Davalli AM, Ogawa Y, Scaglia L et al (1995) Function, mass, and replication of porcine and rat islets transplanted into diabetic nude mice. Diabetes 44:104-111

16. Rao J, Otto WR (1992) Fluorimetric DNA assay for cell growth estimation. Anal Biochem 207:186-192 
17. Leahy JL, Bonner-Weir S, Weir GC (1992) Beta-cell dysfunction induced by chronic hyperglycemia. Current ideas on mechanism of impaired glucose-induced insulin secretion. Diabetes Care $15: 442-455$

18. Makhlouf L, Duvivier-Kali VF, Bonner-Weir S, Dieperink H, Weir GC, Sayegh MH (2003) Importance of hyperglycemia on the primary function of allogeneic islet transplants. Transplantation 76:657-664

19. Andersson A (1983) The influence of hyperglycaemia, hyperinsulinaemia and genetic background on the fate of intrasplenically implanted mouse islets. Diabetologia 25:269-272

20. Davalli AM, Scaglia L, Zangen DH, Hollister J, Bonner-Weir S, Weir GC (1996) Vulnerability of islets in the immediate posttransplantation period. Dynamic changes in structure and function. Diabetes 45:1161-1167

21. Vasir B, Reitz P, Xu G, Sharma A, Bonner-Weir S, Weir GC (2000) Effects of diabetes and hypoxia on gene markers of angiogenesis (HGF, cMET, uPA and uPAR, TGF-alpha, TGFbeta, bFGF and Vimentin) in cultured and transplanted rat islets. Diabetologia 43:763-772

22. Mattsson G, Jansson L, Nordin A, Carlsson PO (2003) Impaired revascularization of transplanted mouse pancreatic islets is chronic and glucose-independent. Transplantation 75:736739
23. Tyrberg B, Ustinov J, Otonkoski T, Andersson A (2001) Stimulated endocrine cell proliferation and differentiation in transplanted human pancreatic islets: effects of the $o b$ gene and compensatory growth of the implantation organ. Diabetes 50:301-307

24. Dionne KE, Colton CK, Yarmush ML (1993) Effect of hypoxia on insulin secretion by isolated rat and canine islets of Langerhans. Diabetes 42:12-21

25. Rabinovitch A, Cuendet GS, Sharp GW, Renold AE, Mintz DH (1978) Relation of insulin release to cyclic AMP content in rat pancreatic islets maintained in tissue culture. Diabetes 27:766773

26. Brissova M, Fowler M, Wiebe P et al (2004) Intraislet endothelial cells contribute to revascularization of transplanted pancreatic islets. Diabetes 53:1318-1325

27. Olsson R, Carlsson PO (2005) Better vascular engraftment and function in pancreatic islets transplanted without prior culture. Diabetologia 48:469-476

28. Hamamoto Y, Tsuura Y, Fujimoto S et al (2001) Recovery of function and mass of endogenous beta-cells in streptozotocininduced diabetic rats treated with islet transplantation. Biochem Biophys Res Commun 287:104-109 